\title{
SAVINGS AND INCOME RELATIONSHIPS AMONG HOUSEHOLDS: A REVIEW OF THE LITERATURE
}

\author{
Daniel Aidoo-Mensah ${ }^{1^{*}}$ \\ ${ }^{1}$ Faculty of Applied Sciences, Methodist University College Ghana, P. O. Box 195 Wenchi - Brong Ahafo \\ Region, Ghana \\ *Corresponding author: danielaidoomensah@gmail.com
}

\begin{abstract}
The paper is a survey of available literature on savings-income functions in developing countries. It gives critical examination of some of the major theories underlining savings and income functions. In doing this, the paper highlighted the concept of savings and some empirical studies done in the area of savings-income relationships and their findings as well as economic implications of the findings. The import of the paper stems from the fact that domestic savings of which household savings is an important component has contributed immensely to the economic transformation of some economies and the determinants of such savings well researched. Hence, understanding the theoretical underpinnings of the savings-income relationships would pave way for further studies to be conducted in Ghana and other developing countries, thereby, replicating such success stories. This is because a better understanding of the savings-income relationship will contribute to the formulation of appropriate policies for savings mobilisation, thereby improving upon local capital formation capacity. Moreover, a good knowledge gained of the savings-income phenomenon particularly at the rural household level in Ghana will give the monetary authorities a fair idea of how the rural economy operates and how to make improvements in this sector to enable its integration into the mainstream financial system.
\end{abstract}

Keywords: households, permanent income, savings, transitory income

\section{INTRODUCTION}

The subject of savings as an engine of economic growth and development has received immense consideration from different authors and schools of thought. It is usually considered together with consumption in most economic theories on savings for the fact that the decision to consume is seen as the opposite to the decision to save. Thus, savings is considered as that part of income not consumed (Goyal, 2007; Family Economics \& Financial Education, 2010; Fisher, 2010; Mbuthia, 2011).

\section{THE CONCEPT OF SAVINGS}

Like most economists, Smith (1776) for instance regarded capital accumulation through savings as a necessary condition for economic development (Rehman et al., 2011). The neoclassical economists made savings a determinant of investment as opposed to the Keynesians who made savings a function of income and income a function of investment (Mikesell \& Zinser, 1973). However, the bottom-line is that savings has been and continues to be of paramount importance in propelling nations to the path of sustained development. Thus, the fundamental challenge has largely been the inability of nations to generate more savings for investment as the rate of investment was determined by the rate of savings given that savings were invested in full. There are two concepts or approaches regarding the measurement of household savings - i. Flow or earned surplus concept and ii. Stock concept.

i. Flow Concept - this measures savings as the excess of current income over current consumption expenditure (Alamgir, 1976). That is, arranging estimated consumption against estimated income (Chowdhury, 1987). This method of estimating savings, according to Alamgir (1976), is equivalent to an estimate of earned surplus and it uses flow concepts alone and in general holds true irrespective of the nature of the unit under study country, region, household or business firm. 
Limitations of this method arise from the fact that income is understated and expenditure overstated (Chowdhury, 1987) and there is no way of cross checking these estimates, and also the method produces a total savings figure without indicating the use or the nature of assets acquired (Alamgir, 1976).

ii. Stock Concept - This is equivalent to estimating savings as the change in earned net worth during a period. While the earned surplus is estimated from the current account, the change in net worth is estimated from its balance sheet. From the balance sheet, saving is measured as changes in physical assets (acquisition minus liquidation and destruction caused by cyclone, floods, use up, fire, river action etc.) plus changes in financial assets (increases minus decreases) less changes in financial liabilities (increase in borrowings minus increase in lendings) less net inflow of capital transfers (inflow minus outflow) less net capital gains (gains minus losses) (Alamgir, 1976).

Much as it is acknowledged that other economic variables such as technological progress, education, institutional development, domestic policies, resource management and the external economic environment may play equally important roles in economic growth and development, it is generally believed that sustained growth and development is difficult to be attained and maintained without savings (Akaah, Dadzie \& Dunson, 1987; Bautista \& Lamberte, 1990). This is because economic growth and development which leans much on these other economic variables cannot be long sustained under conditions of declining savings rates thereby given credence to Lewis' (1954) famous dictum on savings - raising the savings rate is the central problem in economic development (Gersovitz, 1988; Bautista \& Lamberte, 1990).

Though the empirical literature on savings has been couched with a wide variety of theories, Mikesell and Zinser (1973) specified two broad groups:

A. The Keynesian Savings theories and

B. The Non-Keynesian theories

\section{A. THE KEYNESIAN SAVINGS THEORIES}

Keynes (1936) identified absolute income as the main determinant of savings and stressed that savings would increase with absolute income (disposable income) other factors being constant, thus the term absolute income hypothesis. The Absolute Income Hypothesis postulates that the current level of income determines savings. Early studies on savings were built mainly on the Absolute Income Theory. The underlying premise of Keynes' hypothesis is his postulation of a consumption function in which consumption increases at a decreasing rate as income increases. The functional relationship between income $(I)$ and consumption $(C)$ as postulated by Keynes can be expressed as:

$$
C=\alpha+\beta Y
$$

Where $\alpha$ is autonomous consumption and $\beta$ is the marginal propensity to consume out of income, $Y$. Given the definition of savings, $S$ as a residual of household consumption (expenditure) from income, it may be symbolically expressed as:

$$
S=Y-C
$$

Combining equations (1) and (2), Keynesian Savings Functions can be derived as:

$$
S=-\alpha+(1-\beta) Y
$$

The negative intercept denotes dis-saving and the coefficient $(1-\beta)$ of income is termed as the marginal propensity to save (MPS). However, the Keynesian savings function in its most commonly used form is linear with a constant MPS, that is:

$$
S=\beta_{0}+\beta_{1} Y
$$

Where $\beta_{1}$ is the constant MPS. It is assumed that $\beta_{0}<0$ and $0<\beta_{1}<1$ such that as the level of income $(\mathrm{Y})$ rises, average propensity to save $(S / Y)$ will also increase. However, if the intercept, $\beta_{0}$ is positive or $\beta_{1}$ is negative, then average propensity to save (APS) will decrease with increasing income (Mikesell \& Zinser, 1973). 
Though Keynes' analysis followed the more traditional line of demand theory, it relied on a purely static framework in which savings was seen as one of the many "goods" on which the consumer could spend his income. Thus, income was seen as the main determinant of both individual and national savings (Modigliani, 1986). That is why the Keynesian savings function in its most common form is linear with a constant marginal propensity to save (MPS).

Though equation (4) has been the most popular specification of the absolute income hypothesis, several alternative functional forms have been used to achieve a better idea of the movement of the average savings effort over time (Mikesell \& Zinser, 1973). Choudhury (2005) for instance experimented with the following functional forms for explaining savings behavior of Indian households:

$$
\begin{aligned}
& S=a+b Y \\
& \log S=\alpha+\beta \log Y \\
& S=\frac{Y}{a+b Y}
\end{aligned}
$$

$$
S / Y=a+b \log Y
$$

Where $S$ and $Y$ are household savings and income respectively. All the above functional forms are linear. By fitting these four functional forms to time series data (1950-51 to 1962-63) for India, Choudhury (2005) found that the partial logarithmic functional form $\left(S_{t} / Y_{t}=a^{\prime}+b^{\prime} \log Y_{t}\right)$, gives a reasonably close fit to the time series data and thus, encouraging its use for short-term forecasting given the fact that it gives the closest fit not only for the rural area but also for the urban areas and the overall economy.

A summary of the propensities to save (average and marginal) and the income elasticities of savings of functional forms (5) and (8) tested by Choudhury (2005) shows a wide difference between the rural and urban areas of India much

\begin{tabular}{|c|c|c|c|}
\hline $\begin{array}{l}\text { Functional form of savings } \\
\text { function }\end{array}$ & \multicolumn{2}{|c|}{$S_{t}=a+b Y_{t}$} & $S_{t} /_{Y_{t}}=a^{\prime}+b^{\prime} \log Y_{t}$ \\
\hline A. Aggregate & MPS & APS & INCOME ELASTICITY OF SAVINGS \\
\hline Rural & 0.0156 & 0.0206 & 0.7281 \\
\hline Urban & 0.5373 & 0.1752 & 4.0062 \\
\hline Overall & 0.1244 & 0.0561 & 2.5610 \\
\hline \multicolumn{4}{|l|}{ B. PER CAPITA } \\
\hline Rural & 0.0096 & 0.0206 & 0.4671 \\
\hline Urban & 0.8840 & 0.1752 & 6.7693 \\
\hline Overall & 0.2259 & 0.0561 & 4.6933 \\
\hline
\end{tabular}
more than one would normally expect (see Table $1)$.

Table 1. Propensities to Save (Average and Marginal) and Income Elasticity of Savings

Source: Choudhury (2005)

The rural sector of India appears to be an extreme case of unusually low savings and contrary to general expectation, even the income elasticity of savings is less than unity. This according to Choudhury (2005) implies that there is hardly any possibility of increasing rural savings in the near future unless income registers a much more rapid growth than in the past and reaches a certain minimum level essential for savings to increase.
Klein (1954) introduced nonlinearity in the savings function by suggesting the functional form below:

$$
S / Y=b_{0}+b_{1} \log Y
$$

Other ways of introducing nonlinearity in the savings function include the quadratic Keynesian function given as:

$$
S=b_{o}+b_{1} Y+b_{2} Y^{2}
$$


The Singh function (Singh, 1972):

$$
\frac{S}{Y}=b_{o}+b_{1} /(\log Y)^{2}+b_{2} /(\log Y)^{4}
$$

The Musgrove or exponential function (Musgrove, 1974):

$$
\frac{S}{Y}=b_{o}\left[1-\exp \left(-b_{1} Y^{b_{2}}\right)\right]
$$

Though, more suitable from estimation point of view, both Klein and quadratic functional forms suffer from a serious drawback in that they disallow any points of inflexion in the $S-Y$ plane (Bhalla, 1980). The Singh functional form tends not to suffer from the drawback of the Klein and quadratic functional forms. Thus, if $b_{1}<$ 0 and $b_{2}>0$, then the MPS first increases and then converges to long-run APS - a property shared by the exponential or Musgrove functional form.
The APS is bounded form above by $b_{o}$; the APS is not however defined for $Y$ approaching zero (Bhalla, 1980).

Bhalla (1980) compared the four nonlinear forms - the Keynesian quadratic, the Klein, the Singh and the Musgrove (the exponential) forms by using a 1970-71 data of farm earnings of Indian households. Table 2 shows the results of the predicted savings (MPS and APS) of these functional forms.

According to Bhalla (1980), if "fit" was the single most important condition for acceptance, the quadratic savings function would be accepted. Nevertheless, it easily becomes distorted thereby yielding estimates of APS $=39$ percent and MPS = 72 percent at a per capita income level of Rs 3,000; at Rs 4,000 these values become 50 and 92, respectively.

Table 2. Propensities to save (average and marginal) of four nonlinear savings functions

\begin{tabular}{cllllllll}
$\begin{array}{c}\text { Income } \\
\text { Level } \\
\text { per Capita }\end{array}$ & Quadratic & & \multicolumn{2}{c}{ Klein } & & Singh & \multicolumn{3}{c}{ Exponential } \\
& $\overline{R^{2}}$ & .37 & $\overline{R^{2}}$ & .38 & $\overline{\mathrm{R}^{2}}$ & .38 & $\overline{\mathrm{R}^{2}}$ & .36 \\
& SE & .1849 & SE & .1851 & SE & .1856 & SE & .1883 \\
\cline { 2 - 9 } & MPS & APS & MPS & APS & MPS & APS & MPS & APS \\
\hline 200 & 13.4 & -11.4 & 6.2 & -11.0 & 23.7 & -10.5 & 2.2 & .7 \\
500 & 19.7 & 5.4 & 22.0 & 4.8 & 39.3 & 4.6 & 12.7 & 4.4 \\
1,000 & 30.1 & 15.1 & 33.9 & 16.7 & 47.3 & 17.1 & 37.8 & 14.8 \\
1,500 & 40.5 & 21.8 & 40.9 & 23.7 & 51.3 & 23.9 & 53.6 & 25.6 \\
2,000 & 50.9 & 27.8 & 45.8 & 23.6 & 53.8 & 28.4 & 54.0 & 32.9 \\
5,000 & 113.3 & 60.4 & 61.6 & 44.4 & 61.0 & 41.0 & 38.3 & 38.3 \\
7,000 & 154.9 & 81.4 & 67.4 & 50.2 & 63.3 & 45.0 & 38.3 & 38.3 \\
\hline S00 & & & & & & & &
\end{tabular}

Source: Bhalla (1980)

The Klein functional form does not give good estimates like the quadratic form in areas of fit, and its estimates are only slightly better at the high levels of income. For all these functional forms, the marginal and average savings rates are always increasing. The exponential and Singh functional forms give good estimates in terms of fit and also yield similar estimates for the marginal and average propensities to save. The main difference in the two functions lies in their implications for low and high incomes levels. The exponential form gives reasonable estimates along the entire spectrum of income. The estimated asymptotic savings rate is 38 percent, and the maximum MPS (54 percent) is reached at a per capita income level of Rs 2,000.
The Singh functional form, in contrast, does not perform well at either end of the income distribution. At low incomes levels ( $<$ Rs 200) the predicted MPS is 24 percent, and at high incomes (Rs 5,000) the predicted APS is 41 percent and MPS is 61 percent. Similarly, the asymptotic savings rate produced by the Singh form is unusually high (100 percent) and the coefficients for $1 /(\log Y)^{2}$ and $1 /(\log Y)^{4}$ are difficult to understand.

These issues may prompt one to reject the Singh functional form in favour of the exponential form, though it must be noted that the latter requires nonlinear methods and so is 
computationally more difficult to use (Bhalla, 1980). It is interesting to note that the reported $\overline{R^{2}}$ is quite low implying that income per capita is only one of many variables that influence rural savings in developing countries.

Mikesell and Zinser (1973) discussed two other alternative forms of the savings functions as:

$$
\begin{aligned}
& S=b_{o}+b_{1} \operatorname{Ln} Y_{g} \\
& \operatorname{LnS}=c_{o}+c_{1} \operatorname{Ln} Y_{g}
\end{aligned}
$$

Equation (13), according to Mikesell and Zinser (1973) implies that the total level of saving, for $b_{1}>0$, will increase with income, but at an ever decreasing rate. Both propensities to save (average and marginal) tend toward zero at high levels of income. One explanation is that the transition from low to moderate income levels brings an increased awareness of modern consumption opportunities and thus leads to a decreased saving rate. In Equation (14) the term $c_{1}$ represents the constant income elasticity of national saving. Different values of $c_{1}$ imply alternative sets of relationships between the average and marginal propensities to save: if $c_{1}=1$, then APS=MPS; if $c_{1}>1$, then MPS $>$ APS; and if $c_{1}<1$, then MPS $<$ APS (Mikesell \& Zinser, 1973).

In general, it has been established that Keynesian absolute income hypothesis is a significant determinant of savings particularly of rural household savings in developing countries and in most cases; it is found that MPS is higher than APS. However, the degree to which variations in absolute income explain variations in savings seem to be different in various studies (Alamgir, 1976). Moreover, income is generally variable so current income may not fully explain variations in savings. Thus, economists have considered permanent and transitory incomes as better determinants of savings especially among rural economies where incomes are generally characterized by extreme variability or high seasonality (Rodriguez \& Meyer, 1988).

\section{B. NON-KEYNESIAN SAVINGS THEORIES}

Empirical studies on savings in developing countries have utilised two main alternatives to the Keynesian absolute income hypothesis, namely: (a) Friedman's Permanent Income Hypothesis and (b) the Modigliani-Brumberg-Ando (MBA) "Life Cycle Hypothesis". However, a third hypothesis -
Duesenberry's "Relative Income Hypothesis" exists.

The underlying behavioural assumption of Relative Income Hypothesis as developed by Duesenberry (1949) is that the utility of the consumer is derived not from the absolute level of consumption, but from a level that is judged in relation to both the consumer's own past standards and the consumption standards of others. Therefore, a household's consumption is determined not by its absolute income, but by its position in the income scale relative to its reference group basically households in the same income bracket. The consumption function proposed by Duesenberry (1949) can be stated as:

$$
(c / y)_{t}=\alpha+\beta(y / y)_{t}
$$

Where $\beta<0$

Thus, if, overtime, the absolute level of real national income is rising and a household experiences an increase in its absolute income, while maintaining its relative income position on the income distribution scale, its APC remains unchanged. If on the other hand, a household moves to a higher income group its APC will fall to the level of that income group in which the household now finds itself. With this consumption function, Duesenberry could reconcile with the empirical evidences of lower short run MPC compared to higher long run MPC and the variations of short run APC and MPC.

However, limited studies pertaining to developing countries have been done by utilizing the relative income hypothesis. One of such studies which employed the relative income hypothesis in the context of developing countries is the study conducted by Chauhan, Mundle and Jadhav (1972). Their data set was drawn from a sample survey of 87 farmers in Maharastra in India. They defined relative income as the ratio of net income of the household to the arithmetic mean of net household income for the sample and found evidence to support the relative income hypothesis but the limited data base does not permit any useful generalization (Alamgir, 1976).

Although, all the three non-Keynesian hypotheses may differ from one another, they all unite to reject the Keynesian hypothesis. Their rejection is fundamentally based on the fact that over a long period of steady growth state, a rise in per capita income will not in itself bring about a higher savings ratio at least so far as personal income is concerned (Mikesell \& Zinser, 1973). 
The Keynesian hypothesis assumes a savings function which is linear with a constant MPS such that as the level of income rises the savings ratio $(S / Y)$, also increases.

Permanent Income Hypothesis: Subsequent to the pioneering work of Keynes which defines savings as a linear function of income, the first major breakthrough in savings literature is the permanent income hypothesis of Friedman. The hypothesis relates the consumption of a household to its expected long term average income. The level of the expected long term income is thought of as the household's level of "permanent" income that can be safely spent. A household will therefore save only if its current income is higher than the anticipated level of permanent income in order to guard against future declines in income. This assumes that households are able to determine what their long-term consumption needs are and then apportion their resources accordingly in order to cover their life span (Carroll, 2001; Meghir, 2002).

The hypothesis draws a distinction between two components of income - permanent and transitory incomes as determinants of household saving; and indicates that savings are influenced by both components as well as the present level of wealth (both human and non-human) of a household. Permanent income is defined in terms of the longtime income expectation over a planning period and a steady rate of consumption maintained over lifetime given the present level of wealth (Muradoglu \& Taskin, 1996).

Transitory income is defined as that part of income produced by influences that an individual consumer unit or household regards as random and for which the household has not accounted for in planning its budget. That is, transitory income represents spurts (increases and/or decreases) in income which households experience occasionally (Rodriguez \& Meyer, 1988). Thus, transitory income is not observable and some studies have used windfall gains as a proxy for this income (Anthony \& Nosari, 1973) whilst others have estimated it to be the difference between income and permanent income (Mikesell \& Zinser, 1973). The individual's (household) consumption behaviour, though depends on his/her permanent (lifetime) income, his/her savings rate is independent on the level of this permanent income (Bhalla, 1980).

Romer (1996) provides a framework for this hypothesis with an underlying assumption which is made of the consumption behaviour of an individual who lives for $\mathrm{T}$ periods with a lifetime utility given as:

$$
U=\sum_{t=1}^{T}\left(C_{t}\right), u^{\prime}(\cdot)>0 \text { and } u^{\prime \prime}(\cdot)<0
$$

Where $\boldsymbol{u}(\cdot)$ is the instantaneous utility function and $C_{t}$ is the consumption at period, t. Assuming the individual has initial wealth of $A_{o}$ and labour incomes of $Y_{1}, Y_{2} \ldots \ldots \ldots Y_{T}$ for the $\mathrm{T}$ periods of his or her life, the individual can save or borrow at an exogenous interest rate subject to the constraint that any outstanding debt must be repaid at the end of his or her life. It is assumed that the interest rate is set at zero. Thus, the individual's budget constraint is:

$$
\sum_{t=1}^{T} u\left(C_{t} \leq A_{o}+\sum_{t=1}^{T} Y_{t}\right.
$$

Where $\boldsymbol{u}(\cdot)$ is the instantaneous utility function of the individual and $C_{t}$ is his or her consumption at period, t. Since the marginal utility of consumption is always positive, the individual satisfies the budget constraint with equality. The Lagrangian for his maximisation problem is therefore given by:

$$
\mathcal{L}=\sum_{t=1}^{T} u\left(C_{t}\right)+\lambda\left(A_{0}+\sum_{t=1}^{T} Y_{t}-\sum_{t=1}^{T} C_{t}\right)
$$

The first order condition for $C_{t}$ is:

$$
u^{\prime}\left(C_{t}\right)=\lambda
$$

It is assumed that (19) holds for every period of the individual's lifetime, and if that is the case, then his marginal utility of consumption is constant. This implies that his consumption for his entire lifetime is equally constant, a key concept of the hypothesis. Thus:

$$
C_{1}=C_{2}=\ldots \ldots \ldots C_{T}
$$

Putting this fact into the budget constraint yields:

$$
C_{t}=\frac{1}{T}\left(A_{o}+\sum_{\tau}^{T} Y_{\tau}\right) \text { for all } t
$$

The term in parenthesis is the individual's lifetime resources which are divided equally among each period of his/her lifetime. 
Based on this analysis, it implies that the individual's consumption in any given period is determined not by income over that period alone, but by his/her entire lifetime resources made up of $A_{0}$ and $Y_{\tau}$ (Gersovitz, 1988; Romer, 1996). Friedman (1957) referred to this as permanent income implying that consumption is determined by permanent income and the difference between current and permanent income is transitory income.

Equation (21), according to Romer (1996) implies that consumption is determined by permanent income, thus, many empirical studies have found out that households tend to consume out of permanent income and save out of transitory income. To see the importance of the distinction between permanent and transitory incomes, we assume that the individual makes a windfall gain of amount $Z$ in the first period of life. Although, this windfall gained raises current income by $Z$ it raises permanent income by $Z / T$. Thus, if the individual's horizon (life) is fairly long, the impact of the windfall on current consumption tends to be small (Romer, 1996).

Friedman (1957), outlined three salient features of the permanent income hypothesis as:

1. Measured consumption (C) and measured income (Y) are composed of their permanent and transitory components. That is, measured consumption is made of permanent consumption $\left(C_{P}\right)$ and transitory consumption $\left(C_{T}\right)$; measured income is made up of permanent income $\left(Y_{P}\right)$; and transitory income $\left(Y_{T}\right)$, that is:

$$
\begin{aligned}
& C=C_{P}+C_{T} \\
& Y=Y_{P}+Y_{T}
\end{aligned}
$$

2. It is assumed that the transitory components of both consumption and income tend to be stochastically independent, thus:

$$
\begin{gathered}
\operatorname{corr}\left(Y_{P}, Y_{T}\right)=\operatorname{corr}\left(C_{P}, C_{T}\right)=\operatorname{corr}\left(C_{T}, Y_{T}\right) \\
=0
\end{gathered}
$$

There exists a systematic relationship between permanent consumption, $C_{P}$ and permanent income, $Y_{P}$ given by:

$$
C_{P}=k Y_{P}
$$

Where $\mathrm{k}$ is assumed to be independent of $Y_{P}$, that is the independent proposition of the hypothesis. By combining equations (22), (23) and (25), the permanent income hypothesis savings function can be written as:

$$
\begin{gathered}
S=\left(Y_{P}+Y_{T}\right)-\left(C_{P}+C_{T}\right) \\
S=\left(Y_{P}+Y_{T}\right)-\left(k Y_{P}+C_{T}\right) \\
\left.S=(1-k) Y_{P}+Y_{T}-C_{T}\right)
\end{gathered}
$$

A generalized form of (28) is given as:

$$
S=a_{0}+a_{1} Y_{P}+a_{2} Y_{T}+\mu
$$

In its extreme form, the permanent income hypothesis postulates that individuals consume virtually no transitory income; therefore, the MPS out of transitory income will be unity, i.e. $M P S_{T}=$ 1 whilst MPS out of permanent income is zero. Thus, the crucial relationship from the standpoint of empirical tests is the relative sizes of the marginal propensities to save out of permanent and transitory incomes (Mikesell \& Zinser, 1973). However, existing empirical studies do not bear out this strict version of the permanent income hypothesis, but they provide support to the view that the marginal saving rate is higher out of transitory income than out of permanent income (Bautista \& Lamberte, 1990).

The earliest permanent income-oriented study involving data from developing countries is that of Friend and Taubman (1966). They estimated the marginal propensities for 22 countries to be 0.065 and 0.41 for $M P S_{P}$ and $M P S_{T}$ respectively. They postulate that households save as a means of acquiring assets, which are desired for the services they provide. They estimated permanent income as the average of the previous three years income and alternatively, from the relation:

$$
\log Y=a+b t
$$

where $Y$ is income and $t$ is time.

Kelley and Williamson (1968) derived significant estimates of MPS out of permanent income $M P S_{P}$ from 0.20 to 0.29 for Indonesia whilst the range for MPS out of transitory income $M P S_{T}$ was 0.37 to 1.12 ; and Friend (1966) derived an estimate of 0.25 for $M P S_{P}$ for Argentina but found that it was significantly larger than the corresponding $M_{T} S_{T}$ (Mikesell\& Zinser, 1973). Also, Chaudry (1973) found $M P S_{P}$ of 0.06 for a cross-section of some developed countries and 0.04 for some less developed countries and in most of the cases, $M P S_{T}$ was higher than $M P S_{P}$. 
Bhalla (1980) estimated $M P S_{P}$ and $M P S_{T}$ for a sample of rural households in India by specifying three functional forms of the permanent income savings model - linear, linear with transitory consumption $\left(C_{T}\right)$ and a quadratic form. Bhalla disaggregated his sample into all households, subsistence households, intermediate range households (equivalent to middle income households) and rich households. Table 3 gives the results - the marginal propensities of Bhalla's specifications.

Table 3: Marginal propensities (out of permanent and transitory incomes) of Bhalla's specifications

\begin{tabular}{|c|c|c|}
\hline \multirow[t]{2}{*}{ Model } & $\begin{array}{l}\text { Range of MPS out of } \\
\text { permanent income }\end{array}$ & $\begin{array}{l}\text { Range of MPS out of transitory } \\
\text { income }\end{array}$ \\
\hline & \multicolumn{2}{|c|}{ All Households } \\
\hline Linear & 0.21 to 0.23 & 0.30 to 0.27 \\
\hline Linear with transitory consumption $\left(C_{T}\right)$ & 0.22 to 0.24 & 0.34 to 0.30 \\
\hline \multirow[t]{2}{*}{ Quadratic } & 0.09 to 0.07 & 0.30 to 0.27 \\
\hline & \multicolumn{2}{|c|}{ Subsistence Households } \\
\hline Linear & 0.14 to 0.10 & 0.22 to 0.19 \\
\hline \multicolumn{3}{|l|}{ Linear with transitory consumption $\left(C_{T}\right)$} \\
\hline & 0.15 to 0.11 & 0.25 to 0.21 \\
\hline \multirow[t]{2}{*}{ Quadratic } & 0.06 to -0.015 & 0.22 to 0.19 \\
\hline & \multicolumn{2}{|c|}{ Intermediate Households } \\
\hline Linear & 0.26 to 0.32 & 0.33 to 0.32 \\
\hline Linear with transitory consumption $\left(C_{T}\right)$ & 0.28 to 0.32 & 0.38 to 0.34 \\
\hline \multirow[t]{2}{*}{ Quadratic } & 0.03 to 0.22 & 0.33 to 0.30 \\
\hline & \multicolumn{2}{|c|}{ Rich Households } \\
\hline Linear & 0.47 to 0.43 & 0.55 to 0.53 \\
\hline Linear with transitory consumption $\left(C_{T}\right)$ & 0.46 to 0.51 & 0.61 to 0.57 \\
\hline Quadratic & 0.46 to 0.84 & 0.55 to 0.54 \\
\hline
\end{tabular}

Source: Bhalla (1980)

Interestingly, all the studies cited above tend to support the permanent income hypothesis - savings are made out of transitory income except the study of Friend in Argentina in which marginal propensity to save from of permanent income was greater than marginal propensity to save from transitory income.

The Modigliani-Brumberg-Ando (MBA) Life Cycle Hypothesis: The Life Cycle Hypothesis was first formulated in the writings of Modigliani and Brumberg (1954) and later by Ando and Modigliani (1963). It resulted in an important postKeynesian debate that contributed much to the theories regarding savings. It has been widely used to study savings and retirement behaviour of individuals by presenting a well-defined linkage between the consumption plans of the individual and his/her income and income expectations as he/she passes from childhood, through the work participating years, into retirement and eventual decease (Rodepeter \& Winter, 1999).

In its original formulation, the life cycle hypothesis $(\mathrm{LCH})$ presented a theory of savings behaviour by focusing on the individual (or household). Thus, the LCH analysed the savings behaviour of individuals who spread their lifetime consumption over their entire lives by accumulating savings during the earning (working) years and maintaining the same level of consumption during their retirement. It therefore, assumes that individuals plan their consumption and savings behaviour by considering all the different ages of their lives and spreading their income in such a way that today's income will be used to finance tomorrow's consumption (Modigliani \& Brumberg, 1954). This implies that individuals usually do not save up a lot in one period to spend furiously in the next periods but keep their consumption levels approximately the same in every period of their entire lives. Therefore, the key motive to save is to take care of expenses (consumption) after retirement and to acquire wealth, hence the age profile of the household plays an important role in the savings behaviour (Gedela, 2012).

The hypothesis predicts that in any given population, young people will save too little because individuals initially earn relatively little 
and borrow to fulfill their high consumption needs. Middle-aged people with high earnings tend to save the most because within this age bracket an average individual's income increases such that the individual no longer needs to borrow rather tends to save more. The elderly tend to have low or even negative savings rate, because once the individual reaches the retirement age, income drops and dissaving occurs (Nga, 2007).

One of the important implications arising from the $\mathrm{LCH}$ is that the higher the dependency ratio of a household, the lower the aggregate household savings, as these people (the young and the elderly) dis-save. Thus, aggregate savings at any point in time will depend on the savings ratio of the working members of the household.

Empirical studies by Kelley and Williamson (1968), Obwona and Ssentamu (1996), Brata (1999), Amimo et al., (2003), Gedela (2012), and Obayelu (2012) are illustrative of relevant tests of the life cycle hypothesis but with varied results. For instance, Kelley and Williamson (1968) applied the LCH to savings in the Jogjakarta region of Indonesia. They regressed household per capita savings on per capita household income for five age groups by employing the simple life cycle model:

$$
\frac{S}{N}=\alpha+\beta\left(\frac{Y}{N}\right)
$$

Where $\frac{S}{N}$ is household per capita savings and $\left(\frac{Y}{N}\right)$ is household per capita income. They obtained statistically significant results for all the age groups except the 40-49 for which the $\beta$ was negative and also insignificant. Values of $\beta$ increased with age groups of households from 0.046 for the youngest age group (20-29) to 0.599 for the oldest age group (60-69).

The simple life cycle model predicts high average savings rates in 45-64 years (peaking in the 45-54 group) and low savings in the age groups 25 44 years and at retirement (65 years and above). This is however, in contrast to the Indonesian case, suggesting that retirement may be different in Indonesia from that predicted by life cycle model. Nevertheless, the model predicts a rise in the MPS as the household grows older. This prediction is consistent with the Indonesian sample, since income per family member declines up to the age group 40-49 and stabilizes or rises only slightly thereafter (Kelley \& Williamson, 1968).
The empirical work of Obwona and Ssentamu (1996) confirmed the LCH for savings in Uganda by finding that income, wealth and dependency ratio influenced household savings; Brata (1999) found that human capital (education) has positive influence on household savings in Bantul, Indonesia, whilst Amimo et al. (2003) found that square of household physical wealth, household size, age of the household head, age square of household head and education (number of years of schooling of household) have significant influence on household savings with correct a priori signs for all households in the study of household savings of smallholder farmers, entrepreneurs and teachers in rural areas of Kenya.

However, Horioka and Wan (2007) found mixed results for the $\mathrm{LCH}$ as applied to savings by households in China where they found that the variables relating to the structure of the population do not have a significant impact on the household savings rate. Obayelu (2012) in his study of savings behaviour of rural households in Kwara State of Nigeria found a positive relationship between savings rate and age square of household heads implying that in long-run, the proportion of savings to total income increases as the household heads grow old but this is inconsistent with $\mathrm{LCH}$ of savings in which a person is expected to save up to a point and then starts dis-saving as he grows old.

The hypothesis starts with the assumption that consumption needs and income are often unequal at various points in one's life cycle. Young people may be inclined to have consumption needs that exceed their income. Their needs tend to be largely for housing and education, and therefore they have little savings. In middle age, earnings generally rise, enabling debts accumulated earlier in life to be paid off and savings to be accumulated. Finally, in retirement, incomes decline and individuals consume out of previously accumulated savings (Crown, 2002).

According to Rodepeter and Winter (1999), early attempts to establish such a linkage were made by Fisher (1930) and again by Harrod (1948) with his notion of hump savings, but a sharply defined hypothesis which carried the argument forward both theoretically and empirically with its range of well-specified tests for cross-section and time series evidence was first advanced by Modigliani and Brumberg (1954).

Adopting the account of Gersovitz (1988) for Modigliani and Brumberg's formulation for explaining the simplest model of savings of the life cycle hypothesis, we assume a single individual 
who lives for $\mathrm{T}$ periods $(i=0 \ldots \ldots T-1)$, receives income (from labour or sources other than interest payments) of $y_{i}$ and consumes $c_{i}$ in the ith period; the individual neither receives nor leaves bequests. If the individual does not desire that $y_{i}=c_{i}$ he/she can and does borrow or lend at an interest rate $r$ in the ith period. The only constraint on the individual's choices is that the present value of lifetime consumption, $C$, cannot exceed the present value of lifetime income, $Y$ :

$$
C \equiv \sum_{i=0}^{T-1}\left[\frac{c_{i}}{(1+r)^{i}}\right] \leq \sum_{i=0}^{T-1}\left[\frac{y_{i}}{(1+r)^{i}}\right] \equiv Y
$$

The goal of the individual is to maximize the sum, $V$, of the discounted utility of consumption in each period of his/her life, such that:

$$
\delta^{\mathrm{i}} U\left[c_{i}\right], 0<\delta<1
$$

and

$$
V \equiv \sum_{i=0}^{T-1} \delta^{\mathrm{i}} U\left[c_{i}\right]
$$

The utility of consumption in each period is functionally the same, i.e. the function $U[$.$] is time$ invariant. Thus, the individual's problem (for $T=2$ ) is solved by the first-order condition:

$$
U^{\prime}\left[c_{0}\right]=(1+r) \delta^{\mathrm{i}} U\left[c_{i}\right]
$$

which, along with equation (32) holding as an equality, yields optimal values of consumption, $c_{0}^{*}$ and $c_{1}^{*}$. Current savings are then a residual, $y_{0}-c_{0}$, dependent on equations (32) and (34) and the particular time profile of incomes, which is why most theories are formulated and tested in terms of consumption rather than saving functions (Gersovitz, 1988).

The implications of equation (34), according to Hall (1978) are presented in a series of corollaries, which are as follows:

Corollary 1: No information available in period $t$ apart from the level of consumption, $c_{t}$, helps predict future consumption, $c_{t+1}$, in the sense of affecting the expected value of marginal utility. In particular, income or wealth in periods $t$ or earlier are irrelevant, once $c_{t}$ is known.

As stated earlier, assuming the individual neither receives nor leaves bequests, algebraically the individual of age $T$ maximises a utility function of the form:

$$
u=u\left(c_{t}, c_{t+1}, c_{t+2}, c_{t+3}, \ldots \ldots \ldots \ldots \ldots C_{L}\right)
$$

Where $c_{i}(i=t, t+1, t+2, \ldots . . l)$ is the planned consumption at ages $i$ to $l$. $l$ being the individual's expected years at death. In view of the fact that the individual plans to exhaust his/her resources during his/her lifetime budget constraint:

$$
\begin{aligned}
A_{t-1}+Y_{t}+\sum_{i=t+1}^{n} & \frac{Y_{i}^{e}}{(1+r)^{i-t}} \\
& =\sum_{i=t}^{l} \frac{c_{i}}{(1+r)^{i-t}}
\end{aligned}
$$

Where:

$A_{t-1}=$ non-human wealth (physical and financial assets) carried over from the individual's $(t-1)$ year

$Y_{t}=$ individual's earned or non-property income at age $t$

$Y_{i}^{e}=$ individual's expected or non-property income at age $i$

$r=$ interest rate

$n=$ individual's age at retirement

Corollary 2: Marginal utility obeys the regression relation, $u^{\prime}\left(c_{t+1}\right)=\gamma u^{\prime}\left(c_{t}\right)+\varepsilon_{t+1}$, where $\gamma=(1+\delta) /(1+r)$ and $\varepsilon_{t+1}$ is a true regression disturbance; that is, $E_{t} \varepsilon_{t+1}=0$.

Corollary 3: If the utility function is quadratic, $u\left(c_{t}\right)=-\frac{1}{2}\left(\bar{c}-c_{t}\right)^{2}$ (where $\bar{c}$ is the bliss level of consumption), then consumption obeys the exact regression, $\quad c_{t+1}=\beta_{0}+\gamma c_{t}-\varepsilon_{t+1}$, with $\beta_{0}=\bar{c}(r-\delta) /(1+r)$. Again, no variable observed in period $t$ or earlier will have a nonzero coefficient if added to this regression.

Corollary 4: If the utility function has the constant elasticity of substitution form:

$$
u\left(c_{t}\right)=c_{t}^{(\sigma-1) / \sigma} \text {, then the following }
$$

statistical model describes the evolution of consumption: $c_{t+1}{ }^{-1 / \sigma}=\gamma c_{t}{ }^{-1 / \sigma}+\varepsilon_{t+1}$

Corollary 5: Suppose that the change in marginal utility from one period to the next is small, both because the interest rate is close to the rate of time preference and because the stochastic change is small. Then consumption itself obeys a random 
walk, apart from trend. Specifically, $c_{t+1}=\lambda_{t} c_{t}+$ $\varepsilon_{t+1} / u^{\prime \prime}\left(c_{t}\right)+$ higher-order terms where $\lambda_{t}$, is [(1 $+\delta) /(1+r)]$ raised to the power of the reciprocal of the elasticity of marginal utility:

$$
\lambda_{t}=\left(\frac{1+\delta}{1+r}\right)
$$

Modigliani and Brumberg (1954) adopted the simple assumption that the utility function (37) is homothetic. This implies that the planned current consumption of the individual is given by:

$$
c_{t}=\gamma_{t} w_{t}
$$

Where $w_{t}$ is the individual's total expected lifetime resources at age $t$.

Modigliani and Brumberg argued that because their basic LCH model is a simplified model, it may be reliable only under three assumptions: Firstly, in addition to having no inherited assets at the beginning of its life, the individual does not receive any inheritance at any other period of its life; the individual can only accumulate assets through their own saving. Secondly, the proportion of total resources that the individual plans to devote to saving is determined only by his/her tastes and not by the size of his/her resources. Thirdly, the interest rate is zero.

In evaluating the results of these studies, it is important to note that similar studies on the $\mathrm{LCH}$ undertaken in developed countries in most cases used time series data on national savings rates. However, due to the limited availability of similar data in developing countries, similar studies employed cross-sectional data which have proved equally suitable.

\section{TYPES OF SAVINGS}

Savings has long been recognised by economists as a major factor in the process of economic development, directly by its diversion of resources into the formation of capital and indirectly through changes in technology which are implemented when new capital is put to use (Snyder, 1974). Two broad types of savings at the level of the domestic economy may be identified, namely, (1) private savings (made up of the household sector savings and corporate sector savings). The corporate sector savings also being referred to as business sector savings, and (2) public (government) sector savings.

The household sector savings is responsible for a substantial part of domestic savings in both industrial and developing countries, thus, the household sector financial savings forms an integral part of a nation's savings level. These savings are mobilized by financial institutions which allocate them to the most efficient investments. In developed countries where savings ratios tend to be at constant level of 15 to 20 percent, the household sector contributes 10 to 15 percent (Obwona \& Ssentamu, 1996). In the context of the developing countries particularly of East Asia, the average household savings rate in the regions was 30 percent of GDP in the 1990s. For instance, in India in the mid-1950s, households' share in savings stood at 80 percent (Chowdhury, 1987). Even when there has been a dip in the volume of household savings, for example in 197879, that share has been 73 percent (Government of India, 1982).

Household savings efforts have been found to differ among various income groups (Rehman et al., 2011). In general, higher savings rates are associated with the rich and middle income households. Studies of a flow-of-funds nature in developing countries suggest that, while the corporate and government (public) savings categories tend to be deficit sectors, the households constitute the one, if not the major surplus sector (Chowdhury, 1987).

Corporate or business sector savings is savings made by corporate bodies or businesses. This savings is mostly made up of retained earnings. Thus, businesses save when they do not distribute all their profits as dividends to their shareholders. Due to this, households owning shares may not only choose their savings based on their current income but inclusive of corporate retained earnings (Gersovitz, 1988). Corporate savings is usually quite tiny on a macroeconomic scale.

Public sector savings refers to government tax revenue left after spending. It is basically tax revenues less public expenditure. If the government spends more than it collects in taxes, the government runs a budget deficit. If the government collects more revenue than it spends, the government runs a budget surplus.

\section{IMPORTANCE OF SAVINGS TO RURAL HOUSEHOLDS}

Rural households including are vulnerable to a large number of uncertainties and risks related to diseases, conflicts and climatic changes especially erratic rainfall pattern which in most cases affect 
agricultural production - the main stay of the rural economy. However, certain risk mitigation actions can be employed to help overcome or prevent some if not all of these risks. Such actions may include preventative health care systems, free medical care, subsidies on basic goods and services, provision of food hand-outs and public support arrangements such as food for work programmes (Hoogeveen et al., n.d.). Notwithstanding the fact that these risk mitigation measures are important to help rural households to cope with risks and uncertainties, they have the inherent tendency of creating dependency syndrome among rural households (Aidoo-Mensah, 2005). On the other hand, establishment of reliable and appropriate safety nets such as promoting savings habits among rural households can enable them handle some or all these risks and uncertainties on their own with little or no external assistance. Thus, savings can be relied upon as an important tool of improving wellbeing, insuring against times of shocks, and providing a buffer to help people particularly rural households cope in times of crisis with little or no external assistance (Miracle et al., 1980; Zeller \& Sharma, 2000). According to De Laiglesia and Morrisson (2008), besides increasing investment rates in less developed countries, savings is a fundamental tool in the task of lifting rural households to a more sustainable and faster growth development path. Moreover, savings particularly at the household level is needed to finance capital (both physical and human) formation in order to increase output and wellbeing of rural households in developing countries (Bautista \& Lamberte, 1990). Furthermore, relatively underdeveloped financial systems existing in the rural sector mean that accumulation of financial resources is often the only way to acquire productive capital or wealth that can be passed on to future generations (De Laiglesia \& Morrisson, 2008). Apart from its direct contribution to output growth, savings also makes capital accumulation possible enabling the employment of complementary production inputs and serves as a vehicle for the adoption of improved technology (Bautista \& Lamberte, 1990).

Downturns in income or shocks can have severe consequences for rural households particularly those that are struggling to subsist. Even households whose income is adequate, on average may face transitory food insecurity or the risk of it. Savings are therefore needed to maintain adequate consumption levels especially in the periods of food shortages among rural households. For the poorest households, one large shock or a series of small ones can lead to major reductions in food intake, which can lead to permanent disability, especially of children, and lasting impoverishment of the entire household. Thus, the poorer, more risk-averse, and vulnerable a household is, the more important precautionary saving becomes a risk mitigation measure to such a household (International Food Policy Research Institute, 2002).

Savings services are also necessary because many rural households may not be in a position to take advantage of credit for investment into their businesses. This is because investments opportunities in such rural settings may be limited to warrant borrowing. Moreover, in many cases rural households may be too poor and the fluctuations in their incomes and the risks they face are too high for them to rely on borrowing strategies alone to pull them out of poverty. Such households may require other or additional services such as savings besides credit to manage the household budget and risks. In rural settings where some forms of investments opportunities may exist, households may also require savings services to help them better manage their resources over time and to enable them to plan and finance their investments, as borrowing alone is not enough to pull them out of poverty.

It is also significant to note that in many developing countries, more capital is held in the informal economy than in the formal economy. A large part of this capital is held in small amounts by those living near or below the poverty line. Developing countries can bring these numerous small capital holdings into the formal sector by providing poor households with savings services that can meet their needs and made readily accessible to them (Fernando, 1991; Dadzie et al., 1996; Adams, 2002; Sanusi, 2002). This assertion is reinforced by Sexton (1982), in whose view rural savings mobilisation will also improve the resource allocation of the country concerned, particularly because a considerable amount of money saved under informal arrangements is either spent on relatively low-return investments or not made available for investment purposes. In some cases, assets may be kept idle for long periods or invested in prestigious assets like decorative bowls, jewelry 
or saved using in-kind savings vehicles such as livestock, stocks of housing materials and saving in a secret place among others (Aryeetey, 2004; Bendig, et. al., 2009; Bime \& Mbanasor, 2011; Amu \& Amu, 2012).

According to Fernando (1991), promotion of savings habits among rural households and subsequent mobilisation of savings from them by formal institutions would result in an improvement in rural income distribution provided that such institutions pay positive real rates of interest on deposits and keep transaction costs at low levels. Furthermore, it is expected that promotion of savings habits among rural households and subsequent mobilisation of savings from them by formal financial institutions would enable such formal institutions to improve their financial viability and overall performance in many possible ways (Vogel, 1984; Vogel \& Burkett, 1986). One of such ways is that it will enable participating financial institutions gather valuable information on their existing as well as potential borrowers, leading to lower costs on loans to the rural sector (Fernando, 1991). Such valuable information obtained on rural households in the opinion of Fernando (1991), will have positive effect on loan delinquency and reduce risk premium, hence the cost of lending. Moreover, such an effort of extending valuable savings service to rural households by formal financial institutions can be a good step to integrate rural households into mainstream financial system.

\section{MOTIVES FOR SAVINGS}

Much as the socio-economic benefits accruing from savings are varied, so also are the motives or reasons underlying individuals' savings decisions. This is not surprising as research in psychology has identified a hierarchy of saving motives ranging from the more concrete or immediate goals (like consumption), through intermediate goals (like security needs, retirement, debt avoidance and precaution) to the more abstract goals of selfesteem and self-gratification (Canova, Rattazi \& Webley, 2005). Among the early economists to identify savings motives, was Keynes (1936) whose eight savings motives listed below have withstood the test of time:

1. Precaution: Setting aside for unexpected circumstances.

2. Foresight: Meeting anticipated future needs.
3. Calculation: Earning interest.

4. Improvement: Increasing a standard of living over time.

5. Independence: Needing to feel self-sufficient and in control.

6. Enterprise: Investing money into business.

7. Pride: Leaving money to heirs.

8. Avarice or miserliness: Being greedy or tightfisted.

To these motives suggested by Keynes (1936), Browning and Lusardi (1996) added a ninth one, that is, to accumulate deposits (savings) to buy houses, cars and other durables, termed as the down payment motive. Katona (1975) offered six more general motives for saving as follows: (1) for emergencies, (2) to have funds on reserve for necessities, (3) for retirement or old age, (4) for children's needs, (5) to buy a house or durable goods and (6) for holidays.

According to Fisher and Anong (2012) these motives may not necessarily be mutually exclusive but rather complementary. In the opinion of Browning and Lusardi (1996), there is considerable heterogeneity among the motives for saving. In other words, it is unlikely that a single motive will suffice for all members of a population at any given time or even for the same person over a long stretch of time.

However, among these savings motives, precautionary savings motive is considered as one of the most important and this has been confirmed by several empirical studies which show that precautionary savings may contribute to as much as 50 percent of aggregate wealth for individuals under age of fifty (Hurst et al., 2008). For instance, in a study of 2448 respondents in the Netherlands, Mastrogiacomo and Alessie (2012) established that precautionary savings accounted for 30 percent of savings motives among the respondents.

\section{EMPIRICAL REVIEW OF FACTORS INFLUENCING SAVINGS BEHAVIOUR}

Although available evidence according to Alamgir (1976), does not permit any generalization about savings habits in terms of specifying a precise functional form and the variables to be included, it is however, maintained that savings habits are significantly influenced by certain socio-economic and demographic characteristics, cultural and physical variables as well as institutional factors. It is therefore imperative to understand and evaluate 
the relevant significance of these factors (determinants) especially with reference to their applications in studies relating to farm households in developing countries.

\section{HOUSEHOLD DEMOGRAPHIC AND SOCIO-ECONOMIC CHARACTERISTICS}

It has long been established that size of household, age structure and other demographic as well as socio-economic characteristics affect household savings habits (Snyder, 1974), hence their importance for empirical studies on analytical grounds (Leff, 1969). The Life Cycle Hypothesis first proposed by Modigliani and Brumberg (1954) and later by Ando and Modigliani (1963) incorporates various demographic and socioeconomic characteristics as way of explaining consumption and savings behaviour of individuals or households. Empirically, this hypothesis is tested by introducing such demographic characteristics as age of the household head, the dependency ratio and income into the analytic framework used for explaining savings habits of rural households. Among household demographic and socioeconomic characteristics underlying rural savings habits include the following:

\section{Gender of Household Head}

A number of studies have shown that the economic well-being and savings behaviours of men and women differ significantly (Fisher, 2010; JainChandra, 2015). Women particularly those in most developing countries have been found to hold lower levels of wealth and have significantly lower earnings than men (IMF, 2015). In rural areas of South Saharan Africa for instance, women's ability to accumulate assets is governed by family and community norms, which historically have favoured men to the disadvantage of women (Kameri-Mbote, 2005). In addition, the legal systems at the macro level in different countries determine how much control women can have over assets (Chowa, 2006).

Although much is known about differences in income, risk aversion, investment behaviours, and level of wealth among the sexes, little is known about how the factors related to general saving behaviours may differ between men and women (Fisher, 2010). However, it has been found that women spend as many as five more years than men in retirement as a result of having longer life expectancies (Gottschalck, 2008; U.S. Bureau of the Census, 2007). Moreover, it has been reported that women invest their financial resources more conservatively and are, in general, more risk averse than men (Bajtelsmit \&VanDerhei, 1997). Various studies have also found that women have lower rates of participation in retirement plans as compared with men (Sung, 1997) and are more likely to be living in poverty during retirement (Pearce, 1989).

In spite of these shortcomings relating to the female gender as far as financial issues are concerned and despite the importance of saving in regards to the financial security of households, relatively few studies have examined whether there are gender differences in saving at the household level (Fisher, 2010). However, Chowa (2006) has reported that women save better than men when they have the opportunity to save.

\section{Age Structure of Household}

The life cycle hypothesis presents a well-defined age between the consumption plans of an individual and his/her income and expectations concerning future income, as he or she passes from childhood, through the work participating years, into retirement and eventual decease (Spio \& Groenewald, 1996). This implies that household savings are highest during the working years of the head and when income declines during retirement years (Saint-Pierre, 1996), the household draws from their previous savings to maintain the standard of living (Wilson, 2000). Thus, savings is needed by the household to reallocate resources over time thereby smoothing consumption over their life span especially during the retirement age of the household head. Many empirical studies have noted some degree of correlation between the age structure of the household and the savingsincome relationships of households.

The first independent test of the hypothesis was done by Fisher (1956), who conducted a cross section analysis of savings of some 2000 households. Data were sub-classified by age of head of household and by socio-economic group as a proxy for income stability. Current income and liquid asset holdings were used as independent variables. There was evidence of peaking of marginal propensities to save in higher age working groups and a rundown of assets in retirement years. Negative savings were also exhibited in the youngest age groups (Spio \& Groenewald, 1996).

The most searching analysis of the hypothesis was carried by Kelley and Williamson (1968). 
They found that income per family member declines up to the age group 40-49 and stabilises or rises only slightly thereafter.

\section{Household Size}

Household size has relevant implications for household purchasing and spending behaviour (Jerome \& Perreault, 1991), vis-à-vis, savingsincome relationships. All things being equal, it is assumed that households with large family sizes spend more on goods and services than households with small family sizes. Larger family size is therefore found to be associated with greater budget shares devoted to housing and education and all things being equal, this has the tendency to deprive such households enough resources to save and this in most cases results in cyclical poverty (Arthur, 2005). This is more pronounced in rural areas where food and other basic needs consumption, absorb up to 80-90 percent of the household budget. However, in a life cycle context, children may add to the household's productive resources by providing more labour and probably more assets (Chernichovsky, 1978) but in general, household size is supposed to reflect the expenditure pull on household income and the usual expectation is that it will negatively correlate with savings (Alamgir, 1976).

\section{Marital Status of Household Head}

Studies indicate that being married has a large effect on reducing the risk of poverty and is associated with a higher probability of attaining affluence over the life course when compared with non-marriage. Compared to married couples, unmarried people have also been found to save much lower portions of their income and accumulate fewer assets (Grinstein-Weiss, Zhan \& Sherraden, 2004).

From an economic point of view, marriage has several characteristics that may enhance wealth accumulation (Waite, 1995). Grinstein-Weiss et al., 2004 outlined six economic perspectives underlying wealth accumulation vis-à-vis, savings in households where the head is married: First, the total product of a married couple is larger than the sum of the outputs of each produced separately. Second, the institution of marriage entails longterm commitment in which a division of labour enables each spouse to specialize in specific skills and duties. This specialization increases the productivity and the efficiency of the household. Third, economies of scale in consumption suggest that a married couple may achieve the same utility with less combined expenditure than the sum of their individual consumption if living apart. Fourth, the requirements and expectations of married (versus single) life may encourage people to buy a house, save for children's education, and acquire cars and other assets. Fifth, there is persistent evidence that married men earn more than unmarried men. Sixth, the institution of marriage expands one's social network and social support, which may result in additional opportunities and benefits that lead to savings. Finally, married individuals may have access to many benefits such as health and life insurance provided by the spouse's employment which in a way will reduce the pressure on the household income, thereby enhancing the ability to save.

\section{Dependency Ratio}

Age-dependency ratios are a measure of the age structure of the population. They relate the number of individuals that are likely to be "dependent" on the support of others for their daily living - youths and the elderly (that is, the percentage of the population aged 15 years and below together with the percentage of the population aged 65 years and above) to the number of those individuals who are capable of providing such support (OECD, 2007).In defining the dependency ratio, it has been implicitly assumed that the population aged 15 years and below plus 65 years and above adds to household consumption and contributes nothing towards production.

The life cycle model predicts that a relatively large burden of children (and/or the elderly) would cause aggregate savings rates to be relatively small, and that are relatively large size of the older working proportion of the household would reflect a higher aggregate savings rate. The model can therefore be expanded to include the hypothesis of household dependents creating a burden on household savings-income relationships, that is, households provide for the consumption of dependents particularly the younger ones by sacrificing savings in the early stages of household formation and then save at a high rate during the empty-nest stage in order to prepare for retirement (Wilson, 2000). For instance, in an empirical study of 47 countries, Leff (1969) indicated that the dependency rate of the young (those aged 15 and below) and of the old (those aged 65 and above) negatively affected savings rates in those countries. It therefore stands to reason that dependents 
contribute to consumption but not to production, therefore, imposing a constraint on society's potential for savings.

According to Gedela (2012), the dependency burden on savings is more pronounced in developing countries where 70 percent of the population lives in the rural areas. In these areas, children are considered an asset because of their contribution to household activities and farm operations (Amaza et al., 2009). Thus, the impact of the dependency ratio on household savings can be more meaningfully examined if, instead of putting a restriction on the age of the household member, their earning status is explicitly taken into account.

\section{Educational Level of Household Head}

The variable educational status of the household is usually defined as the number of years of formal education attained by the household head. It is usually assumed that a high educational status equips one with better financial management, thereby, impacting positively on savings habits. For instance, Solmon (1975) compared the savings rates of different educational groups and found that both the marginal and average propensities to save tend to rise with the number of years of education. Using longitudinal data from the 1983 and 1986 Surveys of Consumer Finances from the United States, Avery and Kennickell (1991) reported that as respondent education level increased, wealth increased over the three-year-period.

In contrast to the positive relationship between education and savings, Rha, Montalto, and Hanna (2006) found that households with an advanced degree were significantly less likely to save than other wise similar households where the head had a high school diploma. However, the overall conclusion is that increased level of the household head explains a substantial part of the growth of the economic output and increased incomes of households in both developed and developing countries (Johnson, 1990).

\section{Income}

Generally, rural household income has been defined as the sum of the net flow of receipts or earnings from all members of the household from different economic activities during a reference period usually one accounting year (Alamgir, 1976). Such economic activities may include agricultural wages (from crops and livestock; and other related enterprises, non-agricultural wages, remittances, and receipts from property-rentals both in cash and in kind.

Income has been considered the most important factor in the determination of savings not only at the rural household level but at the national level as well. Various empirical studies based on different methodologies conducted in different parts of the world, all found a positive relationship between income and savings (Kodom, 2013). In general, both Keynesian and non-Keynesian savings functions postulate a positive relationship between savings and income. The positive relationship postulated by both models has been confirmed in various empirical studies. For instance, Kudaisi (2013) in her study of West African countries during 1980-2006 confirmed that increase income has a positive effect on household savings. Similarly, Guma and Bonga-Bonga (2016) in their empricial work among corporate and household savings in South Africa as well as Fisher and Anong (2012) in their study of 3,822 nonretired households in the United States all confirmed that increase income has a positive effect on household savings.

\section{INSTITUTIONAL ARRANGEMENTS INFLUENCING SAVINGS BEHAVIOUR}

One of the shortcomings of the economic theories of savings, according to Beverly (1997) is that they are prejudiced towards individuals and households with higher income. The institutional model of savings underscores the fact that suitable institutional arrangements other than income and preferences may play an important role in promoting savings particularly among rural households (Beverly \& Sherraden, 1999). This reinforces the larger message that institutional (either formal or informal) mechanisms play a vital role in any household's decision to save, thus, low saving rates partly stem from a lack of appropriate institutional saving devices, not lack of desire to save on the part of rural households (Armendariz \& Morduch, 2005).

A fundamental difference between the institutional model of savings and the traditional neoclassical economic theory is in the way savings are generated. Whereas the traditional economic theory sees savings as a result of individual choices, the institutional model suggests that savings occur in households largely through appropriate institutional arrangements. Thus, effective asset accumulation can be structured and 
often subsidised through favourable institutional arrangements. Among most households, unstructured savings, which are left over from income minus consumption, are likely to be smaller than asset accumulation generated by institutional arrangements (Grinstein-Weiss et al., 2004).

According to Hussein and Thirlwall (1999), there is no single measure that can capture the institutional determinants of the savings-income relationships of rural households. However, Beverly and Sherraden (1999) propose four institutional determinants of savings: institutionalized saving mechanisms (access), targeted financial education, attractive saving incentives (e.g., matched savings), and facilitation (e.g., payroll deduction). It is therefore posited that a number of institutional arrangements suitable to the rural household setting can elicit from them favourable savings response. These may include the following:

1. Locational convenience - Proximity of the service provider to the clients, that is, the distance covered by the rural household in order to access the nearest savings facility (Akaah et al., 1987; Wright, 1999; Bendig et al., 2009).

2. Cost of transaction, that is, how much it will cost the clients to access the services of the service provider in terms of transportation cost, service charges, and inconveniences if the premises or the office of the service provider is not within a walking distance (Akaah et al., 1987; Wright, 1999; Bendig et al., 2009).

3. Varied range of financial products or services available to the rural household.

4. Speed with which services are provided, that is, how fast or how quick the service provider fulfils the financial requirements of the clients, that is, quick and access to savings without a lot of bureaucracy (Robinson, 2001; Mbuthia, 2011).

5. Simplicity and straightforwardness of transactions - this refers to the ease with which the clients can access financial services from the service provider in terms of language used in filling transactions and the level or extent of the use of technical financial terms or jargons as well as services without a lot of bureaucracy (Wright, 1999; Robinson, 2001; Mbuthia, 2011).
6. Customer-friendly attitude towards clients this is necessary because of the westernised perception of formal institutions by rural folks and therefore the tendency that rural clients would be looked down upon by the staff of the financial institutions (Wright, 1999; Robinson, 2001)

7. Safety or security of savings - how secure the savings of the clients are (Klaehn, Branch \& Evans, 2002).

8. Ability to deposit/save small amounts (Aryeetey \& Gockel, 1991).

9. Flexibility and reliability of service provided

10. Convenience of service hours of opening and closing (Beck et al., 2006; LFS, 2016).

11. Savings density - a measure of the number of financial institutions available to the rural households.

12. Ease and convenience with which one gets access to his/her savings (Rutherford, 1996; Robinson, 2001; Beck et al., 2006; LFS, 2016)

\section{CONSTRAINTS TO PROMOTING SAVINGS HABITS AMONG RURAL HOUSEHOLDS}

In spite of the importance of savings particularly to rural households in developing countries and which therefore calls for the promotion of savings habits among such households, the actual implementation of such a concept may be fraught with many constraints. Though, there are myriads of these constraints, often complex and interrelated as well as confronting rural households' savings habits, they may be looked at from two main points of view, namely - 1. Demand-side constraints, and 2. Supply-side constraints

\section{Demand-side Constraints}

Much as savings plays a vital role in the lives of rural households, available evidence seems to suggest the actual decision regarding the planning and undertaking of savings by most rural households in most developing countries with Ghana being no exception, tends to be difficult for them to take. Thus, the demand-side challenges also referred to as non-policy factors (Akpokodje et al., 2004) and which are mainly behavioural and demographic in nature convey the idea that rural households themselves have a significant part to 
play with regards to forming, improving and maintaining their savings habits.

In the opinion of Bauer (2014), the act of forming a savings habit by most people tends to be difficult for them and therefore, most poor households, an economic bracket which encompasses most rural households have been observed to spend their little disposable income on non-essential items such as alcohol and tobacco rather than saving. As to why people find it difficult to save, Bauer deduced two main reasons. The first of these reasons borders on loss aversion of which researchers have determined that people require much more to give up something they already possess than they are willing to pay for it (Kahneman et al., 1991). In relating this to financial savings, researchers have deduced that setting aside money into a savings account may feel like a loss to most people because it prevents a gain in the current context. Therefore, in the opinion of Bauer (2014), in order to rise above loss aversion, banking and finance institutions should make the gains of savings accounts "more tangible". Thus, labeling accounts for "emergencies," "house" or "retirement" may help remind people why they are saving. In addition to this, providing visual reminders why a savings account was set up may also remind people of future gains and distract them from the loss they are currently experiencing.

Secondly, since these demand-side challenges are basically behavioural in nature and behavioural patterns have been observed to be linked to money habits, it is assumed that the formation of new habits of saving will require the displacement of the old habits of non-saving. In order to achieve this, Bauer (2014) suggested that it may be easiest to make savings deductions automatic any time an income is earned, thus, mimicking the automatic process of a habit formation.

\section{Supply-side Constraints}

Promoting savings habits among rural households and its subsequent mobilisation may be enhanced by appropriate institutional support in the form of suitable policies on rural financial market development and macroeconomic stability. For this reason, supply-side challenges are deemed as fundamentally policy driven factors deemed to have influence on savings habits of rural households. Therefore, in the opinion of Adams (2002), if policy makers, particularly those at the helm of affairs of formal financial intermediaries, assume that rural households are too poor to save, and then implement policies that severely limit their access to savings facilities, one should not be surprised when few savings are mobilised from rural households. This is because most of the policies directed towards rural finance intermediation efforts have been observed to lack appropriate institutional will-power to provide the right institutional arrangements at reaching the rural population with innovative products that meet their needs.

Furthermore, it has been observed that most policies on rural financial intermediation do not take cognizance of the fact that potential depositors in the rural set-up particularly low-income ones are highly sensitive to the transaction costs that are imposed on them by deposit takers, especially the time and distance involved in making small deposits (Wenner \& Proenza, 2003). It therefore goes without saying that rural households must have easy and readily available access to savings facilities since undue absence from their business activities to engage in bank transactions in faraway places means a possible deterioration of their business activities (Aidoo-Mensah, 2005).

Additionally, lack of appropriate policies to ensure sound macroeconomic environment particularly high inflation figures coupled with lack of transparency in governance have been observed to create a not too conducive environment for stability in earnings (incomes), vis-à-vis savings mobilisation and its effective utilisation in investments in most developing countries with Ghana being no exception. It is therefore argued that the necessary pre-conditions for savings promotion among rural households may not exist in most developing countries and this explains the low saving capacity among these countries (Sanusi, 2002). In order to correct this, Sanusi suggests that, there is the need to ensure popular participation in both governance and economic activities, which could generate incomes for the vast majority, and thus enhance savings and investment.

Another challenge identified by Adams (2002) is that despite the rapid multiplication of microfinance organisations in most developing countries, many of these financial intermediaries do not have the required authorization to accept deposits from their clients. Therefore, such microintermediaries are held back in their quest to 
provide voluntary savings opportunities for their clients. Moreover, the virtual collapse of the postal savings systems, as well as many financial cooperatives and some government-owned banks have reduced the opportunities for poor people in many countries to access deposit facilities, especially in rural areas. While formal institutions have worked efficiently in the areas of savings mobilisation in the developed economies, the outcomes of similar efforts in the developing countries have been less than satisfactory. This has been attributed to the financial dualism that characterizes most developing economies which poses serious challenges for savings mobilisation in these economies (Sanusi, 2002).

Another likely reason for the neglect of the promotion of the habit of savings among rural households particularly by microfinance institutions and the subsequent mobilisation of such savings may be explained by Shaw's Law which states that the availability of inexpensive outside funding mostly from donors discourages savings mobilisation by microfinance institutions engaged in rural financial intermediation. By implication, microfinance institutions will only consider promoting savings habits among their clients, thereby mobilising and using such savings for onlending, when there is little or no alternative cheap outside funding available to them (Adams, 2002).

Due to the numerous challenges that militate against savings behaviour of the rural householder particularly the farm household as well as coupled with the current economic downturn in Africa in general and in Ghana in particular, many families both rural and urban have been adversely affected resulting in high levels of poverty and therefore low levels of savings and investment. It is therefore not surprising that many people seem to have high expectation for outside assistance for their economic survival. However, such an expectation can hardly be met in the face of fast dwindling global resources. Nevertheless, both rural and urban households particularly rural farming households can effectively depend on their savings as a key to their financial stability and independence in order to have a cushion to help them weather the unexpected.

\section{CONCLUSION}

A critical examination of most of the aforediscussed theories and their related savings and income functions on one hand underscores the fact that these were basically developed with industrial economies in mind, thus they might be of limited use in developing countries (Ashraf et al., 2003). Deaton (1990) in Ashraf et al. (2003) suggested at least four reasons why these theories might be of limited use in developing nations. First, households in developing countries are larger than in industrialized countries and are more likely to contain several generations. As a result there is less need to save for retirement or for intergenerational transfers. Second, income in many of these economies is uncertain and cyclical, making estimation of longer-term income flows difficult. Third, individuals are likely to be credit constrained, so that borrowing in early years will be difficult. Finally, these combined factors suggest that savings in developing economies often plays an important role in buffering between income and consumption. Furthermore, individuals in developing countries often save small amounts at frequent intervals to smooth income, rather than accumulate or save for retirement.

On the other hand, the studies examined but which have developing economic background were undertaken with estimates based on aggregate data on savings-income interactions at the national level. Hence, very little attention is paid to micro data which tend to have a wealth of information for policy considerations. Most importantly, these large bodies of empirical macroeconomic work ignore heterogeneity among households by assuming a representative household agent. Therefore, these macroeconomic studies hardly deal with "real-world" features that reflect the diversity of savings-income relationships particularly among rural households.

In contrast, the use of micro data analysis which is more desirable particularly in a developing country setting like Ghana allows the estimation of important economic variables and can also help highlight the differences among different household income groups in the savings-income relationships. Moreover, the utilization of micro data can be relied upon to provide accurate information and valuable insights thereby yielding substantially greater precision in the estimation of the relevant parameters than estimates based on aggregate data. This is because some of the relevant explanatory variables at the micro level may exist in a form that cannot readily be aggregated (Aidoo, 2009). In addition, in developing countries, savings are difficult to apprehend as it can be raised on an informal basis. 
As a result, it cannot be completely assessed by the national accounts, in contrast to the developed countries in which saving is largely made up of property investments, monetary and financial investments (Abdelkhalek et al, 2009).

\section{REFERENCES}

Abdelkhalek, T., Arestoff, F., De Freitas, N. M. \& Mage, S. (2009). A microeconometric analysis of households saving determinants in Morocco, African Review of Money Finance and Banking, Vol. 7 No. 27.

Adams, D.W. (2002). Filling the Deposit Gap in Microfinance, notes for the WOCCU Conference on Best Practices in Savings Mobilization, Nov. 5-6, 2002. Washington D.C.

Aidoo, R. (2009). An analysis of yam consumption patterns in Ghanaian urban communities, (Unpublished doctoral thesis) Kwame Nkrumah University of Science \& Technology, Kumasi, Ghana.

Aidoo-Mensah, D. (2005). Factors determining financial product types and demand in post disaster situation - A case study of Sri Lanka after the tsunami. (An unpublished dissertation).Universita Degli Studi Di Bergamo, Italy.

Akaah, I., Dadzie, K. \& Dunson, B. (1987). Formal financial institutions as savings mobilizing conduits in rural LDCs: An empirical assessment based on the bank savings behavior of Ghanaian farm households, Savings and Development.

Akpokodje, G., Egwaikhide, F. O., Oyeranti, O. A. \& Ayodele, O. S. (2004). Savings trend and behaviour in Nigeria. West African Journal of Monetary and Economic Integration: WAJMEI, 4(2).

Alamgir, M. (1976). Rural savings and investment in developing countries: Some conceptual and empirical issues, The Bangladesh Development Studies, Vol. 4 No. 1, pp. 148.

Amaza, P., Abdoulaye, T., Kwaghe, P. \& Tegbaru, A. (2009). Changes in household food security and poverty status in PROSAB area of Southern Borno State, Nigeria.
International Institute of Tropical Agriculture.

Amimo, O., Larson, D., Bittencourt, M. \& Graham, D. (2003). The potential for financial savings in rural Mozambican households, Contributed Paper prepared for presentation at the 25th International Conference of Agricultural Economists International Association of Agricultural Economists (IAAE) 16-22 August 2003 Durban, South Africa.

Amu, M. E. K. \& Amu, E. K. (2012). Saving behaviour in Ghana: A study of rural households in the Ho Municipality of the Volta Region. Online Journal of Social Sciences Research, 1(2), 54-61.

Anthony, W. P. \& Nosari, E. J. (1973). A test of the permanent income hypothesis, Journal of Business Research, Vol. 4 No. 1.

Armendariz, B. A., \& Morduch, J. (2005). Microfinance: Where do we stand? Web Source: Retrieved March 12, 2013 from www.uclouvain.be/cps/.../(9)_Microfinance _ Where_Do_We_Stand.pdf.

Arthur, J, L. (2005). Family size and its socioeconomic implications in the Sunyani Municipality of the Brong Ahafo Region of Ghana, West Africa. (Unpublished MSc. Dissertation). University of Cape Coast.

Aryeetey, E. \& Gockel, F. (1991). Mobilizing domestic resources for capital formation in Ghana (African Economic Research Consortium, Research Paper No. 3). Nairobi, Kenya.

Aryeetey, E. (2004). Household asset choice among the rural poor in Ghana. Paper presented at at the Authors' Workshop for the Project on "Understanding Poverty in Ghana" Organized by the Institute of Statistical, Social and Economic Research, University of Ghana and Cornell University.

Ashraf, N., Gons, N., Karlan, D. \& Yin, W. (2003). A review of commitment savings products in developing countries, The Financial Access Initiative and Innovations for Poverty Action. 
Avery, R. \& Kennickell, A. (1991). Household saving in the US. Review of Income and Wealth, 37(4), 409-432.

Bajtelsmit, V. L., \& VanDerhei, J. A. (1997). Risk aversion and retirement income adequacy. In M. S. Gordon, O. S. Mitchell, \& M. M. Twinney (Eds.), Positioning pensions for the twenty-first century. Philadelphia: University of Pennsylvania Press.

Bauer, R. (2014). How to make savings work for the poor. Web Source: Retrieved August 19, 2014 from https://agenda.weforum.org/2014/08/savingaccounts-habit-research-poverty.

Bautista, R. M. \& Lamberte, B. L. (1990). Comparative saving behavior of rural and urban households in the Philippines, Philippine Institute for Development Studies (PIDS) Working Paper, Vol. 90 No. 15.

Beck, T., Demirguc-Kunt, A. \& Peria, S. M. (2006). Banking services for everyone? barriers to bank access and use around the world (World Bank Policy Research Working Paper No. 4079). Switzerland.

Bendig, M., Giesbert, L. \& Steiner, S. (2009). Savings, credit and insurance: household demand for formal financial services in rural Ghana (GIGA Working Paper No. 94).

Beverly, S. (1997). How can the poor save? Theory and evidence on saving in low-income households (St. Louis Center for Social Development, Washington University Working Paper No. 97-3). Washington.

Beverly, S., \& Sherraden, M. (1999). Institutional determinants of saving: implications for low-income households and public policy. Journal of Socio-Economics, 28, 457-473.

Bhalla, S. S. (1980). The measurement of permanent income and its application to savings behavior, World Bank Reprint Series, No. 172.

Bime, M. J. \& Mbanasor, J. (2011). Determinants of informal savings amongst vegetable farmers in North West Region, Cameroon. Journal of Development and Agricultural Economics 3(12), 588-592.
Brata, A. G. (1999). Household saving behavior: The case of rural industry in Bantul, Analisis CSIS 28(1), 75-86

Browning, M. \& Lusardi, A. (1996). Household saving: Micro theories and micro facts. Journal of Economic Literature, 34(4), 1791-1855.

Canova, L., Rattazzi, A. M. M., \& Webley, P. (2005). The hierarchical structure of saving motives. Journal of Economic Psychology, 26(1), 21-34.

Carroll, C.D. (2001). Precautionary saving and the marginal propensity to consume out of permanent income, NBER Working Paper series, 8233 .

Chaudry, M. A. (1973). An econometric approach to saving analysis, The Pakistan Development Review, Vol. 12 No. 3, pp. 200-231.

Chauhan, K.K.S., Mundle S., \& Jadhav, D. (1972). "Income, savings and investment behaviour of small farmers, Indian Journal of Agricultural Economics, 27.

Chernichovsky, D. (1978). Personal savings and family size and composition: the unresolved issue. Economic and Demographic Change, 345-360

Choudhury, U. D. R. (2005). Income, consumption and saving in urban and rural India", Review of Income and Wealth, Vol. 14 No.1, pp. 3756.

Chowa, G. A. N. (2006). Savings performance among rural households in Sub-Saharan Africa: The effect of gender. International Consortium for Social Development, 28(2), 106-116.

Chowdhury, N. (1987). Household savings behaviour in Bangladesh: Issues and evidence. The Bangladesh Development Studies, 15(3), 1-41.

Crown, W. H. (2002). Life cycle theories of savings and consumption, Encyclopedia of Aging. 
Dadzie, K. Q., Moschis, G. P., Lee E., \& Dadzie, E. W. (1996). Assessing the determinants of bank savings adoption in developing countries: An event history analysis approach. Paper presentation at the American Marketing Association Summer Educators' Conference, San Diego, CA.

Deaton, A. (1990). Saving in developing countries: theory and review. The International Bank for Reconstruction and Development/The World Bank.

De Laiglesia, J. R. \& Morrisson, C. (2008). Household structures and savings: Evidence from household surveys, OECD Development Centre Working Paper No. 267.

Duesenberry, J. S. (1949). Income, saving and the theory of consumer Behaviour, Cambridge: Harvard University Press.

Family Economics \& Financial Education. (2010). What is savings and why is it important? Web Source: Retrieved March 19, 2017 from the website of Family Economics and Financial Education, http://financeintheclassroom.org/downloads/ WhatSavingswhyimportant.pdf.

Fernando N. A. (1991). Mobilising rural savings in Papua New Guinea: myths, realities, and needed policy reforms. The Developing Economies, XXIX-1.

Fisher, I. (1930). The theory of interest, Macmillan Publishing Co.

Fisher, M. R. (1956). Exploration in saving behaviour. Oxford University Institute of Statistics Bulletin, 18, 201-277.

Fisher, P. J. (2010). Gender differences in personal saving behaviors. Association for Financial Counseling and Planning Education.

Fisher, P. J. \& Anong, S. T. (2012). Relationship of saving motives to saving habits. Association for Financial Counseling and Planning Education

Friedman, M. (1957). A theory of the consumption function, Princeton: Princeton University Press.
Friend, I. (1966). The propensity to consume and save in Argentina. Buenos Aires, Argentina: Documento de Trabajo, Centro de Investigaciones Economicas, Instituto Torcuato Di Tella.

Friend, I. \& Taubman, P. (1966). The aggregate propensity to save: Some concepts and their application to international data, Review of Economics and Statistics, Vol. 48 No. 2.

Gedela, S. P. R. (2012). Determinants of saving behaviour in rural and tribal households (An empirical analysis of Visakhapatnam District), International Journal of Research in Social Sciences, Vol. 2 No. 3.

Gersovitz, M. (1988). Saving and Development, in Chenery, H. \& Srinivasan, T.N. (Eds.), Handbook of Development Economics, Elsevier Science Publishers, pp. 381-424.

Gottschalck, A. O. (2008). Net worth and the assets of households: 2002. Washington, DC: U.S. Census Bureau.

Government of India. (1982). Capital Formation and Saving in India 1950-51 to 1979-80. Bombay: Government of India, Reserve Bank.

Goyal, A. (2007). Data and definitions: underestimating savings and investment in an open economy. Indira Gandhi Institute of Development Research, Mumbai

Grinstein-Weiss, M., Zhan, M., \& Sherraden, M. (2004). Saving performance in individual development accounts: does marital status matter? Journal of Marriage and Family, 68, 192-204.

Guma, N. \& Bonga-Bonga, L. (2016). The relationship between savings and economic growth at the disaggregated level. MPRA Paper No. 72131.

Hall, R. E. (1978). Stochastic implications of the life cycle-permanent income hypothesis: theory and evidence. Journal of Political Economy, 86(6), 971-987.

Harrod, R.F. (1948). Towards a Dynamic Economics: Some recent developments of economic theory and their application to policy, London: McMillan. 
Hoogeveen, J., Tesliuc, E., Vakis, R. \& Dercon, S. (n.d.). A guide to the analysis of risk, vulnerability and vulnerable groups. Web Source: Retrieved August 29, 2017 from siteresources.worldbank.org/INTSRM/Publi cations/20316319/RVA.pdf.

Horioka, C. Y. \& Wan, J. (2007). The determinants of household saving in China: A dynamic panel analysis of provincial data, Federal Reserve Bank of San Francisco Working Paper Series, 2007-28.

Hurst, E., Lusardi, A., Kennickell, A. \& Torralba, F. (2008). Precautionary savings and the importance of business owners. Web Source: Retrieved June 16, 2017 from http://faculty.chicagobooth.edu/erik.hurst/re search/precautionary_saving_restat_resubmi ssion final.pdf.

Hussein, K. A., \& Thirlwall, A. P. (1999). Explaining differences in the domestic savings ratio across Countries: A panel data study. Web Source: Retrieved February 15, 2015 from the website of Kent University, http://kar.kent.ac.uk/id/eprint/16857

I.M.F. (2015). Gender and income inequality. Web Source: Retrieved September 16, 2015 from the website of International Monetary Fund, https://www.imf.org/external/pubs/ft/sdn/20 15/sdn1520_info.pdf.

International Food Policy Research Institute (2002). Banking in the Poor - Unleashing the Benefits of Microfinance. International Food Policy Research Institute.

Jain-Chandra, S. (2015). Why gender and income inequality are linked. Web Source: Retrieved September 16, 2015 from the World Economic Forum, https://www.weforum.org/agenda/2015/10/ why-gender-and-income-inequality-arelinked/

Jerome, M. E. \& Perreault, D. W. Jr. (1991). Essentials of Marketing ( $5^{\text {th }}$ Ed). IRWIN Publishers.

Johnson, T. G. (1990). An analysis of the relationship between income distribution and socio-economic development conditions among communities in the Northwest Territories (Unpublished Masters dissertation). University of Saskatchewan, Canada.

Kahneman, D., Knetsch, J. \& Thaler, R. (1991). Anomalies: the endowment effect, loss aversion and status quo bias. The Journal of Economic Perspectives, 5(1), 193-206.

Kameri-Mbote, P. (2005). The land has its owners! Gender issues in land tenure under customary law in Kenya (IELRC Working Paper). UK: International Environmental Law Research Centre.

Katona, G. (1975). Psychological economics. New York: Elsevier.

Kelley, A. C. \& Williamson, J. G. (1968). Household saving behavior in the developing economies: The Indonesian case, Economic Development and Cultural Change, Vol. 16 No. 3, pp. 385-403.

Keynes, J. M. (1936). The general theory of employment, interest, and money. Palgrave Macmillan.

Klaehn, J., Branch, B. \& Evans, A.C. (2002). A technical guide to savings mobilization lessons from the credit union experience. WOCCU.

Klein, L. R. (1954). Statistical estimation of economic relations from survey data, in Klein, L. R., Survey Methods to Economics. New York, NY: Columbia University Press.

Kodom, M. (2013). Savings habit and use of savings among households in Ga-East Municipality. (Unpublished master thesis). University of Ghana, Legon, Accra.

Kudaisi, B. V. (2013). Savings and its determinants in West African countries. Journal of Economics and Sustainable Development, Vol.4, No.18.

Leff, N. H. (1969). Dependency rates and ravings rates. The American Economic Review, 59(5), 886-896.

Lewis, W.A. (1954) Economic development with unlimited supplies of labor, Manchester School of Economic and Social Studies. 
LFS. (2016). Our work: downscaling. Web Source: Retrieved December 10, 205 from LFS financial services' website: http://fsconsulting.de/our_work.

Mastrogiacomo, M. \& Alessie, R. J. M. (2012). The precautionary savings motive and household savings. Netspar Discussion Paper, Vol. 02, No. 009

Mbuthia, A. N. (2011). Households' saving decisions in Kenya. (Unpublished doctoral thesis). The School of Economics of Kenyatta University.

Meghir, C. (2002). A Retrospective on Friedman's Theory of Permanent Income, The Institute for Fiscal Studies WP04/01.

Mikesell, R. F \& Zinser, J. E. (1973). The nature of the savings function in developing countries: A survey of the theoretical and empirical literature, Journal of Economic Literature, Vol. 11 No.1, pp. 1-26.

Miracle, M. P., Miracle, D. S., \& Cohen, L. (1980). Informal savings mobilizationin Africa. Economic Development and Cultural Change, 28(4), 701-724.

Modigliani, F. (1986). Life-cycle, individual thrift, and the wealth of nations, American Economic Review, Vol. 76, pp. 297-313.

Modigliani, F. \& Ando, A. (1963). The 'life cycle' hypothesis of saving: Aggregate implications and tests, American Economic Review, Vol. 53, pp. 55-84.

Modigliani, F. \& Brumberg, R. (1954). Utility analysis and the consumption function: An interpretation of cross-section data, in Kurihara, K. (Ed.), Post Keynesian Economics, New Brunswick: Rutgers University Press.

Muradoglu, G., \& Taskin, F. (1996). Differences in household savings behavior: evidence from industrial and developing countries. The Developing Economies, 34(2), 138-153.

Musgrove, P. (1954). Determination and Distribution of Permanent Household Income in Urban South America. Ph.D. Massachusetts Inst. Tech
Nga, M. T. (2007) An investigative analysis into the saving behaviour of poor households in developing countries: With specific reference to South Africa, (Unpublished Masters dissertation), University of the Western Cape.

Obayelu, O. A. (2012). Saving behavior of rural households in Kwara State, Nigeria, African Journal of Basic \& Applied Sciences, Vol. 4 No. 4, pp. 115-123.

Obwona, M. B. \& Ssentamu, J. D. (1996). Nature and determinants of domestic savings in Uganda, Economic Policy Research Centre, Research Series No. 2.

OECD, (2007). Society at a glance: OECD social indicators. OECD

Pearce, D. (1989). The feminization of poverty: women, work, and welfare. Urban and Social Change Review, 11, 28-36.

Rha, J., Montalto, C. \& Hanna, S. (2006). The effect of self-control mechanisms on household saving behavior. Financial Counseling and Planning, 17(2), 1-16.

Rehman, H., Bashir, F. \& Faridi, M. Z. (2011). Saving behavior among different income groups in Pakistan: A micro study, International Journal of Humanities and Social Science, Vol. 1 No. 10.

Robinson, M. S. (2001).The microfinance revolution: sustainable finance for the poor. The International Bank for Reconstruction and Development/The World Bank. Washington, D.C.

Rodepeter, R. \& Winter, J. K. (1999). Rules of thumb in life-cycle savings models, available at fmwww.bc.edu/RePEc/es2000/1222.pdf.

Rodriguez, J. \& Meyer, R. (1988) "The analysis of saving behaviour: The case of rural households in the Philippines". Manila: The Philippine Institute for Development Studies (PIDS) Working Paper No. 88-20.

Romer, D. (2006). Advanced macroeconomics. New York, NY: McGraw-Hill. 
Rutherford, S. (1996). A critical typology of financial services for the poor. ActionAid and Oxfam, London.

Saint-Pierre, Y. (1996). Do earnings rise until retirement? Perspectives on Labour and Income, 8(2), 32-36.

Sanusi, J.O. (2002). Savings Management in developing countries. An address delivered at the Banking and Financial Services Symposium, organized by the Commonwealth Business Council, London, 3-4th July, 2002.

Sexton, L. D. (1982). Wok Meri: Women's savings and exchange system in Highland Papua New Guinea. Oceania: University of Sydney, 52(3), 167-198.

Shaw, E. S. (1973). Financial deepening in economic development, New York, NY: Oxford University Press.

Singh, S. K. (1972). Determinants of aggregate savings. Economic Working Paper No. 127, World Bank.

Smith, A. (1776). An inquiry into the nature and causes of the wealth of nations, Edition E. Cannan

Snyder, D. W. (1974). Econometric studies of household saving behaviour in developing countries: A survey, The Journal of Development Studies, Vol. 10 No. 2, pp. 139-153.

Solmon, L. (1975). The relation between schooling and savings behavior: an example of the indirect effects of education. In: Juster, S.T. (ed.), Education, income, and human behavior, 253-294.

Spio, K., \& Groenewald, J. A. (1996). Rural household savings and the life cycle hypothesis: the case of South Africa. The South African Journal of Economics, 64(4), 209-304.

Sung, J. (1997). A structural analysis of retirement funds in a family context: participation and investment in stocks. (Unpublished dissertation). The Ohio State University, Columbus, $\mathrm{OH}$.
U.S. Bureau of the Census. (2007).Current population reports. Washington, D. C: U.S. Bureau of the Census.

Vogel, R. C. (1984). Savings mobilisation: The forgotten half of rural finance. In D. Adams (Ed.), Undermining rural development with cheap credit. Boulder, Co: Westview Press.

Vogel, R. C. \& Burkett, P. (1986). Deposit mobilisation in developing countries: the importance of reciprocity in lending. Journal of Developing Areas, 29(4).

Waite, L. J. (1995). Does marriage matter? Demography, 32(4), 483-507.

Wenner, M. D. \& Proenza, F. J. (2003). Rural finance in Latin America and the Caribbean: challenges and opportunities. In $\mathrm{M}$. D.Wenner, J.Alvarado \&F.Galarza, (Eds.), Promising practices in rural finance Experiences from Latin America and the Caribbean. Centro Peruano de EstudiosSociales, Inter-American Development Bank and Academia de Centroamerica.

Williamson, J. G. (1968). Personal savings in developing nations: An inter-tem-poral cross-section from Asia, Economic Record, Vol. 44, pp. 194-210.

Wilson, S. J. (2000). Demographic and institutional influences on Canadian savings behavior (Unpublished $\mathrm{PhD}$ Thesis). Queen's University, Kingston, Ontario, Canada.

Wright, G. A. N. (1999). A critical review of savings services in Africa and elsewhere. MicroSave.

Zeller, M. \& Sharma, M. (2000). Many borrow, more save and all insure: Implications for food and micro-finance policy. Food Policy, 25(2), 143-167. 